\section{Study on biofiltration capacity and kinetics of nutrient uptake by Gracilaria cervicornis (Turner) J. Agardh (Rhodophyta, Gracilariaceae)}

\author{
Marcella A. A. Carneiro, ${ }^{1}$ Fúlvio Aurélio de M. Freire, ${ }^{2}$ Eliane \\ Marinho-Soriano ${ }^{*}, 1$
}

${ }^{1}$ Departamento de Oceanografia e Limnologia, Universidade Federal do Rio Grande do Norte, Brazil,

${ }^{2}$ Departamento de Botânica, Ecologia e Zoologia, Universidade Federal do Rio Grande do Norte, Brazil.

\begin{abstract}
The absorption efficiency and kinetic parameters $\left(\mathrm{V}_{\max }, \mathrm{K}_{\mathrm{s}}\right.$ and $\left.\mathrm{V}_{\max }: \mathrm{K}_{\mathrm{s}}\right)$ of the seaweed Gracilaria cervicornis for the nutrients $\mathrm{NH}_{4}^{+}, \mathrm{NO}_{3}^{-}$and $\mathrm{PO}_{4}^{3-}$ were evaluated. Absorption efficiency was measured by monitoring nutrient concentrations for $5 \mathrm{~h}$ in culture media with initial concentrations of $5,10,20$ and $30 \mu \mathrm{M}$. Kinetic parameters were determined by using the Michaelis-Menten formula. Absorption efficiencies for this algae were greater in treatments with lower concentrations, as evidenced by a reduction of $85.3,97.5$ and $81.2 \%$ for $\mathrm{NH}_{4}^{+}$, $\mathrm{NO}_{3}^{-}$and $\mathrm{PO}_{4}^{3-}$, respectively. Kinetic parameters show that G. cervicornis exhibits greater ability to take up high concentrations of $\mathrm{NH}_{4}^{+}\left(\mathrm{V}_{\max }=158.5 \mu \mathrm{M} \mathrm{g}_{\mathrm{dw}}{ }^{-1} \mathrm{~h}^{-1}\right)$ and low concentrations of $\mathrm{PO}_{4}{ }^{3-}\left(\mathrm{K}_{\mathrm{s}}=5 \mu \mathrm{M}\right.$ and $\left.\mathrm{V}_{\max }: \mathrm{K}_{\mathrm{s}}=10.3\right)$. These results suggest that this algal species has good absorption capacity for the nutrients tested and may be a promising candidate as a bioremediator of eutrophized environments.
\end{abstract}

Revista Brasileira de Farmacognosia Brazilian Journal of Pharmacognosy 21(2): 329-333, Mar./Apr. 2011

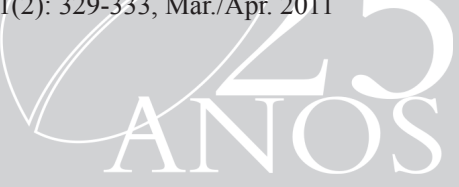

\section{Article}

Received 23 Dec 2010

Accepted 22 Jan 2011 Available online 6 May 2011

Keywords: Gracilaria nutrient uptake macroalgae

ISSN 0102-695X doi: 10.1590/S0102-695X2011005000074

\section{Introduction}

Seaweeds are particularly efficient nutrient absorbers and possess specific mechanisms for storing large amounts of nitrogen and phosphorous in their tissues (Lobban \& Harrison 1997). These nutrients may be used in the future when, for example, the environmental concentrations fall to levels lower than those required by the seaweeds for growth (DeBoer, 1981).

Studies related to nutrient removal by seaweeds have been conducted to select species that can be used as biofilters for the treatment of eutrophized environments (Chopin et al., 2001; Buschmann et al., 2001; Troell et al., 2003; Neori et al., 2004). The seaweeds most widely used in this type of experiment belong to the genus Gracilaria. For example, in an integrated salmon/seaweed system, Buschmann et al. (1996) demonstrated that Gracilaria chilensis was capable of removing $95 \%$ of ammonium and $32 \%$ of phosphorous. Other integrated studies with Gracilaria gracilis also demonstrated a high capacity for removing these nutrients: around $93 \%$ and $62 \%$ of ammonium and phosphorous, respectively (Hernández et al., 2002; Martínez-Aragón et al., 2002). More recently, Marinho-Soriano et al. (2009) showed that Gracilaria caudata was capable of reducing the concentrations of ammonium, nitrate and orthophosphate to 59.5, 49.6 and
$12.3 \%$, respectively, in only $4 \mathrm{~h}$.

Nutrient uptake rates achieved by seaweeds are generally based on the reduction of the concentration of a given nutrient in the culture medium. In these studies, kinetic parameters $\left(\mathrm{V}_{\max }\right.$ and $\left.\mathrm{K}_{\mathrm{s}}\right)$ are quite useful for identifying the physiological abilities of a seaweed (Phillips \& Hurd, 2004), supplying valuable data to help in the selection of species that can be used as biofilters in eutrophized environments. The aim of the present study was to obtain information on the filtration capacity and the kinetics of uptake of $\mathrm{NH}_{4}^{+}, \mathrm{NO}_{3}^{-}$and $\mathrm{PO}_{4}^{3-}$ by the seaweed Gracilaria cervicornis (Turner) J. Agardh.

\section{Materials and Methods}

Algal material and preculture conditions

The seaweeds used in this experiment were collected at the Buzios beach in the Northwest of Brazil $\left(06^{\circ} 01^{\prime} \mathrm{S}-35^{\circ} 06^{\prime} \mathrm{W}\right)$ and taken to the laboratory, where epiphytes and sediment were removed. Before the experiment, the seaweeds were maintained for $24 \mathrm{~h}$ in seawater $\left(\mathrm{NH}_{4}^{+}<1 \mu \mathrm{M}, \mathrm{NO}_{3}{ }^{-}<1 \mu \mathrm{M}\right.$ and $\mathrm{PO}_{4}{ }^{3-}$ undetectable $)$ with constant aeration and illuminated $(180 \mu \mathrm{mol}$ photon $\mathrm{m}^{-2} \cdot \mathrm{s}^{-1}$ ) in a $10 \mathrm{~h}$ light $-14 \mathrm{~h}$ dark cycle at a temperature of 
$28.6 \pm 0.5^{\circ} \mathrm{C}$ and salinity of $37.8 \pm 0.2 \mathrm{PSU}$. The samples used in the absorption experiment were selected from this stock.

\section{Experimental design}

The absorption efficiency of $G$. cervicornis for $\mathrm{NH}_{4}^{+}, \mathrm{NO}_{3}^{-}$and $\mathrm{PO}_{4}^{-3}$ was determined by monitoring these nutrients at initial concentrations of 5, 10, 20 and $30 \mu \mathrm{M}$. For each concentration, transparent cylindrical recipients (triplicate) containing $5 \mathrm{~g}$ of $G$. cervicornis and filled with $1 \mathrm{~L}$ of filtered seawater were used. To obtain the desired concentrations, previously prepared solutions containing $\mathrm{NH}_{4} \mathrm{Cl}\left(\mathrm{NH}_{4}^{+}\right), \mathrm{KNO}_{3}\left(\mathrm{NO}_{3}^{-}\right)$and $\mathrm{KH}_{2} \mathrm{PO}_{4}\left(\mathrm{PO}_{4}^{3-}\right)$ were added to the seawater. A recipient containing only enriched seawater served as the control. The experiment lasted for $5 \mathrm{~h}$, with samplings at 15 $\min , 30 \mathrm{~min}, 1 \mathrm{~h}, 2 \mathrm{~h}, 3 \mathrm{~h}, 4 \mathrm{~h}$ and $5 \mathrm{~h}$. To ensure that none of the nutrients ( $\mathrm{N}$ and $\mathrm{P}$ ) would become limiting for G. cervicornis, a molar ratio of 10:1 (N:P) was used (Friedlander \& Dawes, 1985). Water samples were analyzed according to Strickland \& Parsons (1972). After the last sampling, the seaweeds were immediately removed and oven dried $\left(60{ }^{\circ} \mathrm{C}\right)$ to obtain the dry weight. Absorption efficiency was calculated based on the reduction in the concentration of nutrients for each sampling period and expressed in percentages.

Uptake rates $\left(\mu \mathrm{M} g_{d w}{ }^{-1} h^{-1}\right)$ were calculated for each time interval during the depletion according to Pedersen (1994): $V=\left[\left(S_{0} \cdot V_{o l}\right)-\left(S_{1} \cdot V o l_{1}\right)\right] /(B \bullet t)$, where $\mathrm{S}_{0}$ and $\mathrm{S}_{1}$, are the substrate concentrations and $\mathrm{Vol}_{0}$ and $\mathrm{Vol}_{1}$, the volumes before and after a sampling period $(t)$, and $\mathrm{B}$ is algal dry weight biomass $(\approx 0.5 \mathrm{~g})$.

Uptake rates $(V)$ between $0-15 \mathrm{~min}$ were plotted against each corresponding mean substrate concentration and the Michaelis-Menten function: $V=V_{\max } S /\left(K_{s}+S\right)$, was fitted to the data by regression, where $V_{\max }$ is the maximum uptake rate $\left(\mu \mathrm{M} \mathrm{g}_{\mathrm{dw}}{ }^{-1} \mathrm{~h}^{-1}\right)$ and $\mathrm{Ks}$ is the half-saturation constant.

\section{Statistical analyses}

All data were tested for normality (Kolmogorov-Smirnov test) and homoscedasticity (Levene's test). One-way ANOVA was used to determine the variations between the time intervals monitored, followed by the Student-Newman-Keuls post-hoc test for multiple comparisons of means (Zar, 1999). The Michaelis-Menten function was analyzed for significance by using the Table Curve ${ }^{\circledR}$ 2D 5.0, 2000 program. Statistical analyses were conducted with SigmaStat v2.03 software.

\section{Results}

Absorption of nutrients by $G$. cervicornis was significant at all concentrations analyzed (ANOVA, $p<0.05$ ), with the lowest values being recorded in the first 15 min of incubation and the maximum values at the end of the experiment (3-5 h) (Figure 1). The absorption efficiency of $G$. cervicornis was greatest at the lowest initial concentration $(5 \mu \mathrm{M})$, showing the greatest percent reduction for $\mathrm{NO}_{3}^{-}(97.5 \%)$, followed by $\mathrm{NH}_{4}^{+}$ $(85.3 \%)$ and $\mathrm{PO}_{4}{ }^{3-}(81.6 \%)$. In the treatments with initial concentrations of 20 and $30 \mu \mathrm{M}$, higher $\mathrm{NH}_{4}^{+}$absorption was observed, followed by $\mathrm{NO}_{3}{ }^{-}$and $\mathrm{PO}_{4}{ }^{3-}$. No variations in nutrient concentrations were observed in the controls (ANOVA; $p>0.05$ ) (Table 1).

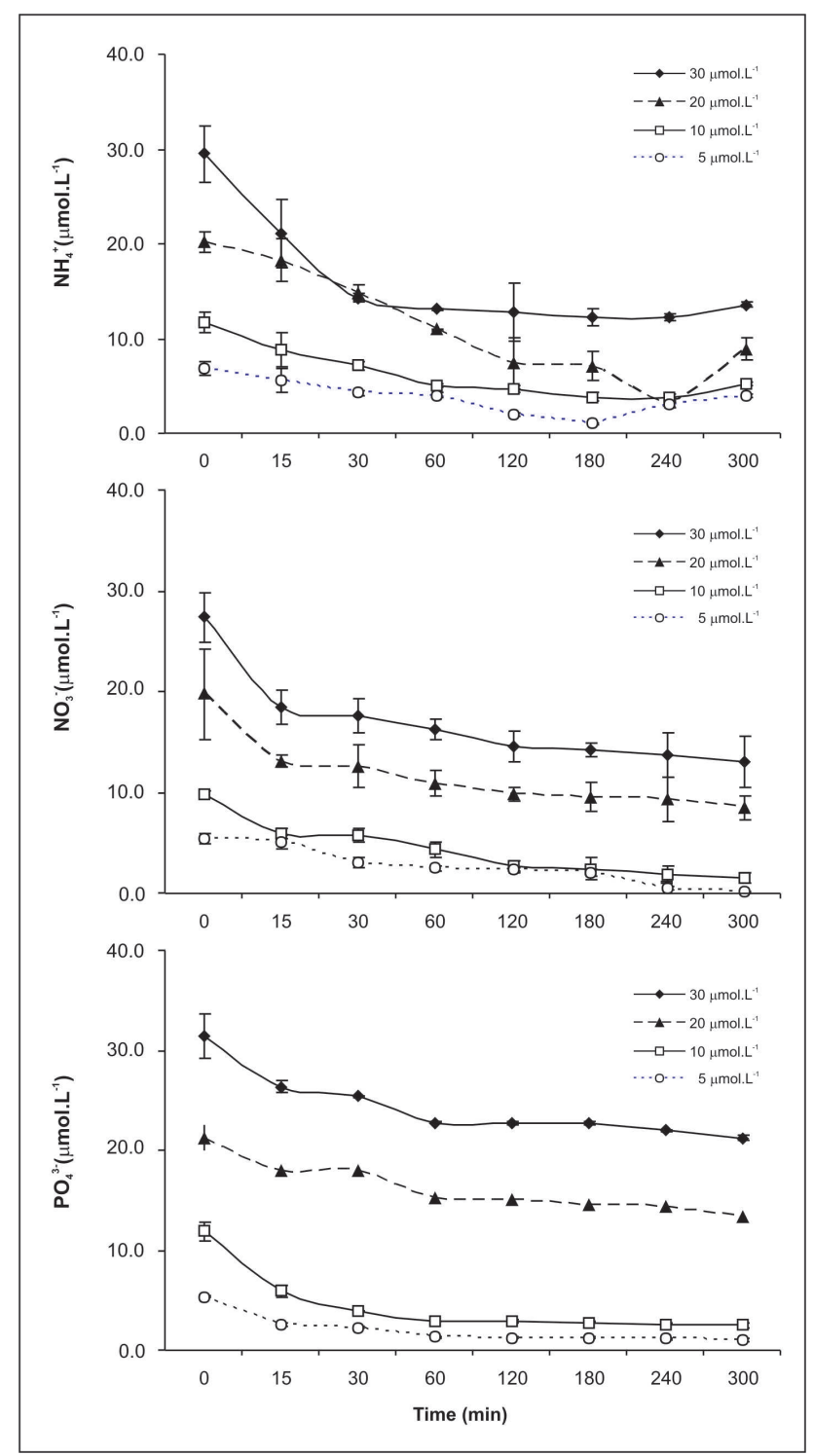

Figure 1. Depletion of the concentrations of $\mathrm{NH}_{4}^{+}, \mathrm{NO}_{3}{ }^{-}$and $\mathrm{PO}_{4}^{3-}$ during the $5 \mathrm{~h}$ experiment with G. cervicornis. 
Table 1. Initial and final concentrations of $\mathrm{NH}_{4}^{+}, \mathrm{NO}_{3}^{-}$and $\mathrm{PO}_{4}^{3-}$ in the control and G. cervicornis groups for treatments with $5,10,20$ and $30 \mu \mathrm{M}$ of the nutrient and the absorption efficiency (\%) of the seaweed at the end of the experiment (3-5 h).

\begin{tabular}{|c|c|c|c|c|}
\hline & & $\begin{array}{c}\text { Control } \\
\left(\mathrm{C}_{\text {intital }}-\mathrm{C}_{\text {final }}\right)\end{array}$ & $\begin{array}{l}\text { Treatments } \\
\left(\mathrm{C}_{\text {initial }}-\mathrm{C}_{\text {final }}\right)\end{array}$ & $\begin{array}{c}\text { Absorption } \\
\text { efficiency (\%) }\end{array}$ \\
\hline \multirow{4}{*}{${\stackrel{\mathbf{Z}^{+}}{+}}^{+}$} & $5 \mu \mathrm{M}$ & $5.2-5.4$ & $6.8-1.0$ & 85.3 \\
\hline & $10 \mu \mathrm{M}$ & $11.5-11.8$ & $11.7-3.7$ & 68.0 \\
\hline & $20 \mu \mathrm{M}$ & $20.4-20.5$ & $20.2-3.5$ & 82.9 \\
\hline & $30 \mu \mathrm{M}$ & $30.5-30.3$ & $29.5-12.3$ & 58.3 \\
\hline \multirow{4}{*}{$\stackrel{0}{n}^{m}$} & $5 \mu \mathrm{M}$ & $5.2-5.6$ & $5.4-0.1$ & 97.5 \\
\hline & $10 \mu \mathrm{M}$ & $10.8-10.3$ & $9.7-1.5$ & 84.6 \\
\hline & $20 \mu \mathrm{M}$ & $20.7-20.7$ & $19.7-8.4$ & 57.3 \\
\hline & $30 \mu \mathrm{M}$ & $30.0-30.5$ & $27.3-13.0$ & 52.6 \\
\hline \multirow{4}{*}{$\stackrel{\dot{m}}{\circ}^{+}$} & $5 \mu \mathrm{M}$ & $5.3-5.3$ & $5.3-1.0$ & 81.6 \\
\hline & $10 \mu \mathrm{M}$ & $11.7-11.5$ & $11.8-2.5$ & 79.1 \\
\hline & $20 \mu \mathrm{M}$ & $20.7-20.4$ & $21.2-13.2$ & 37.5 \\
\hline & $30 \mu \mathrm{M}$ & $30.8-30.1$ & $31.3-21.2$ & 32.5 \\
\hline
\end{tabular}

Higher uptake rates $(V)$ were obtained from 0 to $15 \mathrm{~min}$. Uptake rates for the three nutrients decreased over the course of the experiment and are illustrated on a hyperbolic curve (Figure 2). As the external concentration of nutrients increased, the velocity showed a tendency to saturation (Figure 2A, B and C). Kinetic parameters from the Michaelis-Menten equation obtained for the three nutrients are shown in Table 2. The seaweed $G$. cervicornis exhibited the highest $V_{\max }$ and $\mathrm{K}_{\mathrm{s}}$ values in the experiment with $\mathrm{NH}_{4}^{+}\left(158.5 \mu \mathrm{M} \mathrm{g}_{\mathrm{dw}}{ }^{-1} \mathrm{~h}^{-1}\right.$ and 41.6 $\mu \mathrm{M})$. On the other hand, $\mathrm{PO}_{4}^{3-}$ had the lowest $V_{\max }$ and $\mathrm{K}_{\mathrm{s}}$ values $\left(51.5 \mu \mathrm{M} \mathrm{g}_{\mathrm{dw}}{ }^{-1} \mathrm{~h}^{-1}\right.$ and $5 \mu \mathrm{M}$, respectively). The $V_{\text {max }}$ :Ks ratio (10.3) was higher for $\mathrm{PO}_{4}^{3-}$.

Table 2. Kinetic parameters $\left(\mathrm{V}_{\max }, \mathrm{K}_{\mathrm{s}}\right.$ and $\left.\mathrm{V}_{\max }: \mathrm{K}_{\mathrm{s}}\right)$ of the Michaelis-Menten equation obtained from the rates for uptake of $\mathrm{NH}_{4}^{+}$. $\mathrm{NO}_{3}^{-}$and $\mathrm{PO}_{4}^{3-}$ by G. cervicornis.

\begin{tabular}{cccc}
\hline & $\mathrm{V}_{\max }\left(\mu \mathrm{Mg}_{\mathrm{dw}}{ }^{-1} \mathrm{~h}^{-1}\right)$ & $\mathrm{K}_{\mathrm{s}}(\mu \mathrm{M})$ & $\mathrm{V}_{\max }: \mathrm{K}_{\mathrm{s}}$ \\
\hline $\mathrm{NH}_{4+}$ & 158.5 & 41.6 & 3.8 \\
$\mathrm{NO}_{3-}$ & 67.9 & 19.6 & 3.5 \\
$\mathrm{PO}_{4}^{3-}$ & 51.5 & 5.0 & 10.3 \\
\hline
\end{tabular}

\section{Discussion}

This study showed a significant removal of the three nutrients by the seaweed G. cervicornis, with greater biofiltration efficiency for the two forms of nitrogen than for orthophosphate. The maximum absorption efficiency values obtained in this experiment $\left(85.3 \%-\mathrm{NH}_{4}^{+} ; 97.5 \%-\mathrm{NO}_{3}^{-}\right.$and $\left.81.2 \%-\mathrm{PO}_{4}{ }^{3-}\right)$ were similar and at times higher than data found in the literature. Jones et al. (2001) observed that, in wastewater treatment using seaweeds, Gracilaria edulis was capable of reducing the $\mathrm{NH}_{4}^{+}$concentration by $74 \%(2 \mathrm{~h}), \mathrm{NO}_{3}^{-}$by $97.7 \%(4$ h) and $\mathrm{PO}_{4}^{3-}$ by $95.1 \%(10 \mathrm{~h})$. In an experiment using Gracilariopsis longissima, Hernández et al. (2006) recorded mean filtration efficiencies of $93.2 \%$ for $\mathrm{NH}_{4}{ }^{+}$ and $62.2 \%$ for $\mathrm{PO}_{4}{ }^{3-}$ after $7 \mathrm{~h}$ of incubation.

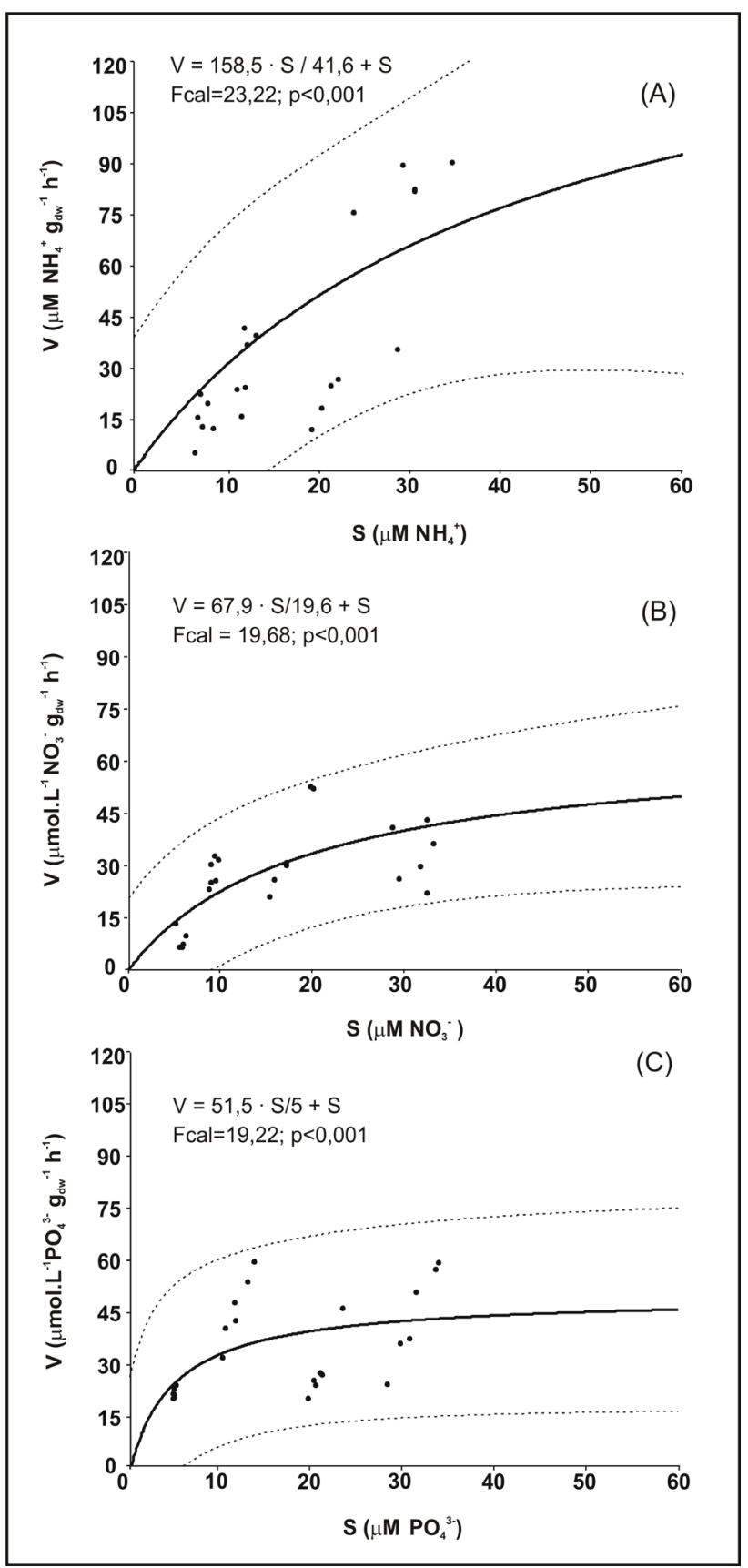

Figure 2. Uptake rates (V) for $\mathrm{NH}_{4}^{+}(\mathrm{A}), \mathrm{NO}_{3}{ }^{-}(\mathrm{B})$ and $\mathrm{PO}_{4}{ }^{3-}(\mathrm{C})$ as a function of substrate concentrations $(\mathrm{S})$. Curves fitted to the Michaelis-Menten equation. $p$-value $<0.001$ indicates that the independent $(\mathrm{S})$ and dependent $(\mathrm{V})$ variables follow this function. The dashed lines delimit the prediction interval at the $95 \%$ confidence level. 
With respect to uptake rate, G. cervicornis showed reduced values as the incubation time increased. At the end of the experiment, rates were less than $15 \%$ of those obtained at the beginning. This pattern was also observed by other authors for several seaweed species (Pedersen, 1994; Campbell, 1999; Dy \& Yap, 2001; Pedersen et al., 2004).

The rate of uptake of $\mathrm{NH}_{4}^{+}$by $G$. cervicornis was greater than that of $\mathrm{NO}_{3}^{-}$at all concentrations tested. This behavior has been generally observed for a number of seaweed species (D'Elia \& DeBoer, 1978; Wallentinus, 1984; Phillips \& Hurd, 2004), given that the process of $\mathrm{NO}_{3}{ }^{-}$absorption and assimilation is more costly to seaweeds than those for $\mathrm{NH}_{4}^{+}$(McGlathery et al., 1996).

Maximum uptake rates $\left(V_{\max }\right)$ and half-saturation constants $\left(\mathrm{K}_{\mathrm{s}}\right)$ are generally the most widely used parameters for comparing and contrasting uptake rates in seaweeds. $\mathrm{K}_{\mathrm{s}}$ is normally used to estimate the ability of a species to absorb a nutrient at low concentrations, while $V_{\max }$ estimates the maximum uptake rate at high concentrations (Raven \& Taylor, 2003). Table 3 shows $V_{\max }$ and $\mathrm{K}_{\mathrm{s}}$ values for various seaweed species. The $V_{\max }$ values for $G$. cervicornis are higher than those recorded for other species of Gracilaria. The high $V_{\max }$ obtained for $\mathrm{NH}_{4}^{+}$suggests that G. cervicornis performs better in environments where the concentration is high and where it can uptake $\mathrm{NH}_{4}^{+}$at a rate proportional to its concentration in the water column. This ability may be an advantage for seaweeds cultivated in eutrophized environments.

In this study, G. cervicornis also exhibited high $V_{\max }$ values for nitrate. This rapid absorption of $\mathrm{NO}_{3}$ from the medium suggests that this species is highly competitive in removing this nutrient from water. The nitrogen uptake rate was always higher than that of phosphorous at the same concentrations. In relation to $\mathrm{PO}_{4}^{3-}$, there are few studies on the uptake kinetics of this nutrient, probably reflecting the fact that orthophosphate concentrations are often near the detection limit (Lobban \& Harrison, 1997).

However, seaweeds found in eutrophic environments may exhibit very high $\mathrm{K}_{\mathrm{s}}$ and $V_{\max }$ values, such as the species Ulva and Chaethomorpha, which exhibit $\mathrm{K}_{\mathrm{s}}$ values of $3.5-10 \mu \mathrm{M}$ and $V_{\max }$ values of 8.5$20.8 \mu \mathrm{M} \mathrm{g}_{\mathrm{dw}}{ }^{-1} \mathrm{~h}^{-1}$ (Lavery \& McComb, 1991). The high absorption rate recorded in this study for the three nutrients should represent an advantage for this species when nutrient availability in the environment is high. This being so, G. cervicornis can be considered to be an important species for bioremediation in eutrophized environments and in integrated aquaculture.

\section{Acknowledgements}

CAPES.

This research was supported by the CNPq and

\section{References}

Buschmann AH, Troell M, Kautsky N, Kautsky L 1996. Integrated tank cultivation of salmonids and Gracilaria chilensis (Gracilariales Rhodophyta). Hydrobiologia 326/327: 75-82.

Buschmann AH, Troell M, Kautsky N 2001. Integrated algal farming: a review. Cah Biol Mar 42: 83-90.

Campbell SJ 1999. Uptake of ammonium by four species of macroalgae in Port Phillip Bay, Victoria, Australia. Mar Freshwater Res 50: 515-522.

Chopin T, Buschmann AH, Halling C, Troell M, Kautsky N, Neori A, Kraemer GP, Zertuche-Gonzales JA, Yarish C, Neefus C 2001. Integrating seaweeds into marine aquaculture systems: a key toward sustainability. $J$ Phycol 37: 975-986.

DeBoer JA 1981. Nutrients. In Lobban CS \& Wynne MJ (eds), The biology of seaweeds. Oxford: Blackwell Scientific, p. 356-392.

D'Elia CF, DeBoer JA 1978. Nutritional studies of two red algae. II. Kinetics of ammonium and nitrate uptake. $J$ Phycol 14: 266-272.

Dy, DT, Yap HT 2001. Surge ammonium uptake of the cultured seaweed, Kappaphycus alvarezii (Doty) Doty (Rhodophyta: Gigartinales). J Exp Mar Biol Ecol 265: 89-100.

Friedlander M, Dawes CJ 1985. In situ uptake kinetic of ammonium and phosphate and chemical composition of the red seaweed Gracilaria tikvahiae. J Phycol 21:

Table 3. Comparison of $\mathrm{V}_{\max }\left(\mu \mathrm{Mg}_{\mathrm{dw}}{ }^{-1} \mathrm{~h}^{-1}\right)$ and $\mathrm{K}_{\mathrm{s}}(\mu \mathrm{M})$ values for several species of seaweeds.

\begin{tabular}{|c|c|c|c|c|c|c|c|}
\hline \multirow{2}{*}{ Species } & \multicolumn{2}{|c|}{$\mathrm{NH}_{4}^{+}$} & \multicolumn{2}{|c|}{$\mathrm{NO}_{3}^{-}$} & \multicolumn{2}{|c|}{$\mathrm{PO}_{4}^{3-}$} & \multirow{2}{*}{ Reference } \\
\hline & $\mathrm{V}_{\max }$ & $\mathrm{K}_{\mathrm{s}}$ & $\mathrm{V}_{\max }$ & $\mathrm{K}_{\mathrm{s}}$ & $\mathrm{V}_{\max }$ & $\mathrm{K}_{\mathrm{s}}$ & \\
\hline Gracilaria pacifica & 21.5 & 50.9 & 6.0 & 26.8 & --- & --- & Thomas \& Harrison (1987) \\
\hline Gracilaria foliifera & 23.8 & 1.6 & 9.7 & 2.5 & --- & --- & D’Élia \& DeBoer (1978) \\
\hline Agardhiella subulata & --- & --- & --- & --- & 0.5 & 0.4 & DeBoer (1981) \\
\hline Cladophora montagneana & 130 & 20.7 & 42.1 & 1.4 & 3.6 & 0.5 & Gordon et al. (1981) \\
\hline Enteromorpha compressa & --- & --- & --- & ---- & 48.7 & 10.6 & Raven \& Taylor (2003) \\
\hline Gracilaria cervicornis & 158.5 & 41.6 & 67.9 & 19.6 & 51.5 & 5.0 & Present study \\
\hline
\end{tabular}


448-453.

Gordon D M, Birch PB, McComb AJ 1981. Effects of inorganic phosphorus and nitrogen on the growth of an estuarine Cladophora in culture. Bot Mar 24: 93-106.

Hernández I, Martínez-Aragón JF, Tovar A, Pérez-Lloréns JL, Vergara JJ 2002. Biofiltering efficiency in removal of dissolved nutrients by three species of estuarine macroalgae cultivated with sea bass (Dicentrarchus labrax) waste waters 2. Ammonium. J Appl Phycol 14: 375-384.

Hernández I, Pérez-Pastor A, Vergara JV, Martinez-Aragón JF, Fernández-Engo A, Pérez-Lloréns JL 2006. Studies on the biofiltration capacity of Gracilariopsis longissima: From microscale to macroscale. Aquaculture 252: $43-$ 53.

Jones AB, Dennison, WC, Preston NP 2001. Integrated treatment of shrimp effluent by sedimentation, oyster filtration and macroalgal absorption: a laboratory scale study. Aquaculture 193: 155-178.

Lavery PS, McComb AJ 1991. The nutritional ecophysiology of Chaetomorpha linum and Ulva rigida in Peel Inlet, Western Australia. Bot Mar 34: 251-260.

Lobban CS, PJ Harrison 1997. Seaweed Ecology and Physiology. Cambridge: Cambridge University Press.

Marinho-Soriano E, Panucci RA, Carneiro MAA, Pereira DC 2009. Evaluation of Gracilaria caudata J. Agardh for bioremediation of nutrients from shrimp farming wastewater. Biores Technol 100: 6192-6198.

Martínez-Aragón JF, Hernández I, Pérez-Lloréns JL, Vázquez R, Vergara JJ 2002. Biofiltering efficiency in removal of dissolved nutrients by three species of estuarine macroalgae cultivated with sea bass (Dicentrarchus labrax) waste waters 1. Phosphate. J Appl Phycol 14: 365-374.

McGlathery KJ, Pedersen MF, Borum J 1996. Changes in intracellular nitrogen pools and feedback controls on nitrogen uptake in Chaetomorpha linum (Chlorophyta). J Phycol 32: 393-401.

Neori A, Chopin T, Troell M, Buschmann A H, Kraemer G P, Halling C, Shpigel M, Yarish C 2004. Integrated aquaculture: rationale, evolution and state of the art emphasizing seaweed biofiltration in modern mariculture. Aquaculture 231: 361-391.

Pedersen MF 1994. Transit ammonium uptake in the macroalga Ulva lactuca (Chlorophyta): Nature, regulation and the consequences for choice of measuring technique. $J$ Phycol 30: 980-986.

Pedersen A, Kraemer G, Yarish C 2004. The effects of temperature and nutrient concentrations on nitrate and phosphate uptake in different species of Porphyra from Long Island Sound (USA). J Exp Mar Biol Ecol 312: 235-252.

Phillips J, Hurd CL 2004. Kinetics of nitrate, ammonium, and urea uptake by four intertidal seaweeds from New Zealand. J Phycol 40: 534-545.

Raven JA, Taylor R 2003. Macroalgal growth in nutrientenriched estuaries: A biogeochemical and evolucionary perspective. Water Air Soil Poll 3: 7-26.

Strickland JDH, Parsons TR 1972. A practical handbook of seawater analysis. Ottawa: Fisheries Research Board of Canada.

Thomas TE, Harrison PJ 1987. Rapid ammonium uptake and nitrogen interactions in five intertidal seaweeds grown under field conditions J Exp Mar Biol Ecol 107: 1-8.

Troell M, Halling C, Neori A, Chopin T, Buschmann AH, Kautsky N, Yarish C 2003. Integrated mariculture: asking the right questions. Aquaculture 226: 69-90.

Zar JH 1999. Biostatistical Analysis, 4 ed. New Jersey: Prentice Hall.

Wallentinus I 1984. Comparisons of nutrient uptake rates for Baltic macroalgae with different thallus morphologies. Mar Biol 80: 215-225.

\section{*Correspondence}

Eliane Marinho-Soriano

Departamento de Oceanografia e Limnologia, Universidade Federal do Rio Grande do Norte 59014-100 Natal-RN, Brazil eliane@ufrnet.br

Tel.: +558433424950

Fax: +55 8434234951 